\title{
HIV-1 Viral Load and CD4 Assessment in HIV-1 Infected Pregnant Women Supported as Part of PMTCT in N'Djamena, Chad
}

\author{
Adoum Fouda Abderrazzack ${ }^{1,3}$, Mounerou Salou ${ }^{2,4}$, Yaovi Ameyapoh ${ }^{3}$, \\ Mahamat Nour Aguid ${ }^{5}$, Bertin Tchombou Hig-Zounet ${ }^{6}$, Adawaye Chatte ${ }^{7}$, \\ Abdelsalam Tidjani ${ }^{8}$
}

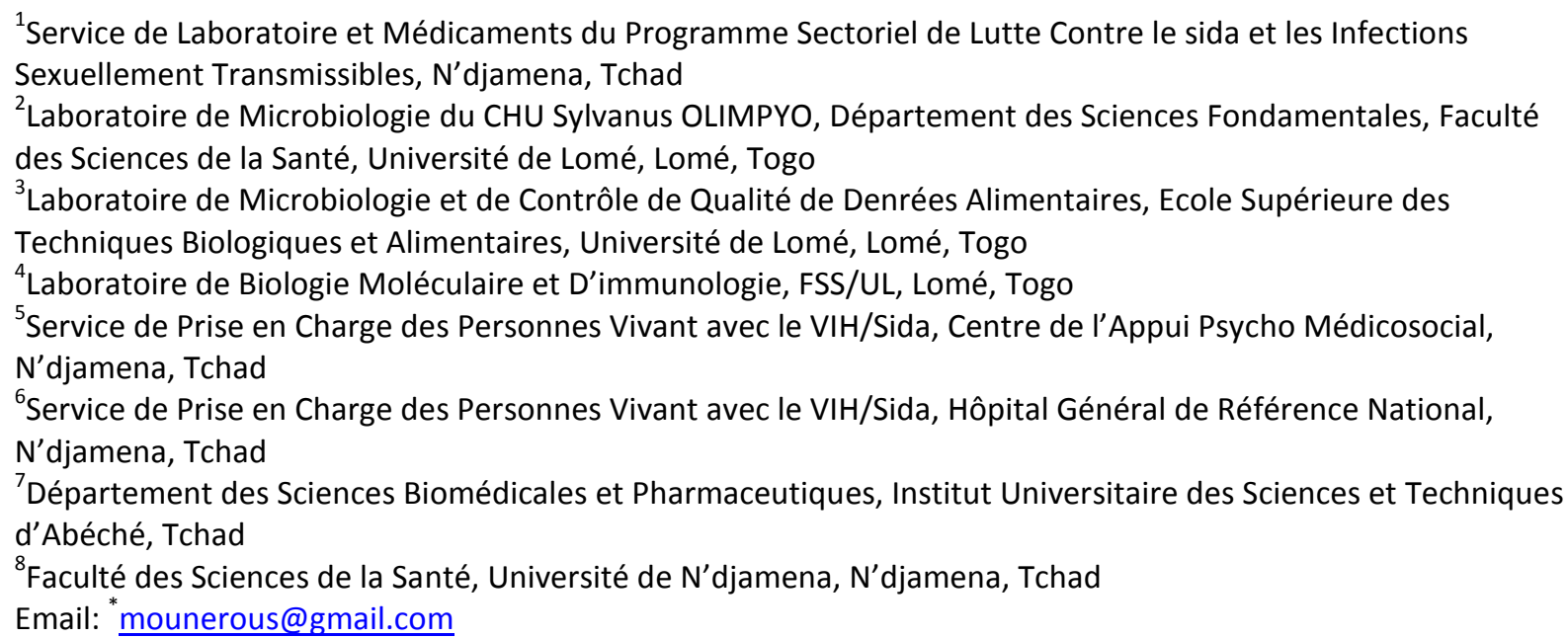

Received 23 August 2015; accepted 22 September 2015; published 25 September 2015

Copyright (C) 2015 by authors and Scientific Research Publishing Inc.

This work is licensed under the Creative Commons Attribution International License (CC BY).

http://creativecommons.org/licenses/by/4.0/

(c) (i) Open Access

\section{Abstract}

In Sub-Saharan Africa, HIV affects lots of women of childbearing age; without prevention they can transmit the virus to their child. A cross-sectional study was conducted in the center of Psycho Medico-Social Support (APMS) in N'Djamena, Chad from January 2014 to March 2015. Our sampling concerned HIV-1 infected pregnant women followed up for PMTCT and their newborn. CD4+ lymphocytes and HIV-1 viral load were tested respectively with PIMA ${ }^{\mathrm{TM}}$ and Abbott m2000 Real Time in mothers. Early infant diagnosis of HIV-1 was done in Children using PCR tool (Abbott m2000 Real Time). Pregnant women included in the study had a median age of 25 years (IQR, 22 30 years). Most of them (75.6\%) (34/45), were under combination ART (TDF + 3TC or FTC + EFV).

\footnotetext{
"Corresponding author.
} 
The median duration on ART was 4 month (IQR [3 - 5 months]). Nevirapine syrup was administrated to newborns as prophylaxis at least for the first six weeks of life until EID was done. At ART initiation, mothers' LTCD4+ median was 249 cells $/ \mathrm{mm}^{3}$ (IQR: 95 - 674 cells $/ \mathrm{mm}^{3}$ ). After a median duration of 4 months on ART, LTCD4+ median was 530 cells $/ \mathrm{mm}^{3}$ (IQR [263 - $\left.1220 \mathrm{cells} / \mathrm{mm}^{3}\right]$ ). Viral load assessment in mothers showed that $15.5 \%(7 / 45)$ were undetectable, $75.6 \%(34 / 45)$ were detectable with a VL $<3 \log$ copies/ml and $8.8 \%(4 / 45)$ at virologic failure (VL > 3log copies/ $\mathrm{ml})$. Four (11.4\%) of 35 children included were tested positive at EID for HIV-1. Antiretroviral treatment management in pregnant women can improve their health and reduce the risk of MTCT. Availability of virologic monitoring in routine is essential for pregnant women in resources limited setting for preventing HIV transmission to their new-born and keep them alive.

\section{Keywords}

\section{Pregnant Woman, Child, HIV, ART, LTCD4, Viral Load, PCR}

\section{Introduction}

The HIV/AIDS epidemic remains a public health problem worldwide [1]. In sub-Saharan Africa, the most affected area by the epidemic, the number of women aged 15 to 49 , potentially affected by the risk of transmitting the virus to their child during the perinatal period is estimated at more than 13 million (59\%) [2]-[4]. The HIV-1 mother to child transmission (MTCT) can occur in utero, during birth and after birth through breastfeeding [5] [6] and the risk increases when LTCD4+ rate is $<350$ cells $/ \mathrm{mm}^{3}$ [5]. The rate of MTCT is correlated to HIV-1 viral load [7]. The mainly way of acquired HIV-1 infection in children is from mother-to-child (vertical transmission) [8] [9]. The first trials on the effectiveness of antiretroviral prophylaxis during pregnancy to prevent mother to child transmission (PMTCT) of HIV-1 have shown a reduction in number of new infections among children borned to HIV infected mothers in 1994 [4] [10]. The advent of triple antiretroviral therapy (ART) in 1996 has contributed to reducing significantly MTCT rates [11]-[16]. Thus, World Health Organization (WHO) has made recommendations towards resources limited countries to promote the use of ARVs drugs in HIV infected pregnant women and their newborns for PMTCT. These recommendations started in 2004 with the option A which consists of short course antepartum Zidovudine (AZT) with single-dose Nevirapine (sd NVP) at labour followed by AZT + 3TC (lamivudine) during 7 days postpartum for the mothers and for the children sd NVP at birth followed by daily NVP until 1 week after all exposure for breastfeeding or AZT or NVP until 4 - 6 weeks for non-breast feeding children [17], option B in 2006 [17], which is an initiation of a prophylactic ART regimen as early as 14 weeks of pregnancy until the end of breastfeeding for the mothers. In option $\mathrm{B}$, infants borned to women receiving ART should also receive standard prophylaxis with daily zidovudine (AZT) or NVP at birth and for an additional 4 - 6 weeks period regardless of breastfeeding. In 2013, the latest recommendation for PMTCT (option $\mathrm{B}+$ ) advocates lifelong ART for all pregnant women infected with HIV regardless of either the clinical stage or the number of LTCD4. For women who develop treatment failure during pregnancy or during the breastfeeding period, the second-line treatment should be imposed [18]. In Chad, a country where HIV prevalence is $3.3 \%$ in the general population, and $2.9 \%$ among pregnant women [19], a PMTCT program is available since 2001. The country is implementing the WHO protocols for HIV PMTCT. The early infant diagnosis using PCR tools for children aged $<18$ months is implemented in Chad since 2007 [20]. Under the PMTCT program, the number of pregnant women who received antiretroviral prophylaxis increased from 834 in 2010 to 1680 in 2012 [21]. This study was undertaken to appreciate the intervention of a support website associative field in the PMTCT program. We aimed to assess both HIV-1 viral load level and LTCD4+ rate in pregnant women receiving antenatal care in an associative health care center in $\mathrm{N}^{\prime}$ djamena (Chad) and to determine the rate of HIV-1 transmission among their children.

\section{Patients and Methods}

It is a cross sectional study conducted in the center of the Medico Support Psycho (APMS) in N'Djamena, Chad. 
From January 2014 to March 2015, we included, HIV-1 infected pregnant women with a gestational age $>32$ weeks of amenorrhea, on ART and followed-up for PMTCT and their newborns aged $>6$ weeks tested in the HIV early infant diagnosis (EID) program.

\subsection{Samples Collections}

Of mothers, about $10 \mathrm{ml}$ of venous blood were collected at the elbow fold in 2 EDTA tubes. In infants, dried blood spot (DBS) sample was obtained onto paper Whatman 903.

\subsection{Counting of CD4+ Lymphocytes}

The CD4+ were counted in the laboratory of the APMS using a PIMA ${ }^{\mathrm{TM}}$ brand apparatus (Alere Technologies GmbH, Loebstedter Str. 103-105 D-07749 Jena, Germany, 2014).

\subsection{Measurement of HIV-1 Viral Load}

Using an insulated refrigerated chamber at $4^{\circ} \mathrm{C}$ (Vaccine Carrier), samples for viral load measurement were transported to the virology laboratory unit at the "Hôpital General de Reference National" (HGRN). Two plasma aliquots (about $1 \mathrm{ml}$ ) were made and stored at $-20^{\circ} \mathrm{C}$ until the Viral Load (VL) testing. The determination of the $\mathrm{VL}$ in plasma sample and early infant diagnosis (EID) in infants were made using Abbott RealTime HIV-1 m2000 (PI 51-608381 R1 Carla Moreira, 2011). EID was undertaken after a pre-extraction step according to the protocol of ABBOTT (PI 51-608381R1 Carla Moreira, 2011).

The socio-demographic informations and ART histories for pregnant women and their children were collected using a standardized survey form.

\subsection{Ethics}

Coordination of support Psycho medico (APMS) has approved for conducting the study under references (No. 196/PR/PM/ MSPASSN/DG/PSLS-IST/PMSS/2013). All mothers have freely given their consent to participate to the study.

\subsection{Statistical Analysis}

Data were analyzed using Excel and Epi Info version of 2007. The significance was set at $\mathrm{p}<0.05$.

\section{Results}

During the study period, 45 HIV-1 infected pregnant women on ART and 35 children borned to 35 mothers were included. There was not a twin pregnancy; the median age of women was 25 years with interquartile range (IQR) [22 - 30 years]. Most of them (34/45) (75.6\%) were married and more than half of them (24/45) (53.3\%) were multiparous. Socio-demographic characteristics of these women are recorded in Table 1. The mean gestational age was 32 weeks. Among them (34/45) (75.6\%) were receiving combination ART (TDF + 3TC/FTC + EFV), (10/45) (22.2\%) were under AZT + 3TC + NVP versus (1/45) $(2.2 \%)$ which benefited from a protease inhibitor-based regimen (AZT + 3TC + LPV) (Table 1). The median duration on ART was 4 months IQR [3 - 5 months]. The mean age of the 35 children tested was 8 weeks. All these children have taken Nevirapine syrup as PMTCT prophylaxis during the first six weeks of life.

The median rate of LTCD4+ at ART initiation was 249 cells $/ \mathrm{mm}^{3}$ with IQR [95 - $\left.674 \mathrm{cells} / \mathrm{mm}^{3}\right]$. The median rate LTCD4+ at the time of sampling was $530 \mathrm{cells} / \mathrm{mm}^{3}$ (IQR, $263-1220$ cells $/ \mathrm{mm}^{3}$ ). Seven (15.6\%) of the 45 women enrolled had a HIV-1 viral load undetectable versus (38/45) $(84.4 \%)$ viremic women. Among viremic subjects, (89.5\%) (34/38) had a VL < 1000 copies/ml and (10.5\%) (4/38) were above 1000 copies/ml (3log copies $/ \mathrm{ml}$ ) (Table 1). Thus, the rate of virologic failure (VF) was $(8.8 \%)(4 / 45)$ (Table 1) according to World Health Organization guidelines from 2013.

The HIV-1 MTCT rate was (11.4\%) (4/35). All of the 4 children tested HIV-1 infected, were borned to multiparous mothers and 3 of them were borned to married women with VL less than 1000 copies/ml and CD4 count between 200 and 500 cells $/ \mathrm{mm}^{3}$. 
Table 1. Characteristics of pregnant women.

\begin{tabular}{|c|c|c|}
\hline Parameter & Outcomes & \\
\hline \multicolumn{3}{|l|}{ Age (years) } \\
\hline & Median, (IQR) & $25(22-30)$ \\
\hline & $15-20 \mathrm{n},(\%)$ & $7(15.55)$ \\
\hline & $20-35 \mathrm{n},(\%)$ & $19(42.22)$ \\
\hline & $25-30 \mathrm{n},(\%)$ & $10(22.22)$ \\
\hline & $30-35 \mathrm{n},(\%)$ & $8(17.77)$ \\
\hline & $35-40 \mathrm{n},(\%)$ & $1(2.22)$ \\
\hline \multicolumn{3}{|l|}{ Marital status } \\
\hline & Single $n,(\%)$ & $2(4.4)$ \\
\hline & Married n, $(\%)$ & $34(75.6)$ \\
\hline & Divorced, n, (\%) & $9(20)$ \\
\hline \multicolumn{3}{|l|}{ Parity } \\
\hline & Nulliparous, n, (\%) & $6(13.3)$ \\
\hline & Primipare $n,(\%)$ & $15(33.3)$ \\
\hline & Multipare n, (\%) & $24(53.3)$ \\
\hline \multicolumn{3}{|l|}{ ART regimen } \\
\hline & $\mathrm{TDF}+3 \mathrm{TC}$ or FTC + EFV n, (\%) & $34(75.6)$ \\
\hline & $\mathrm{AZT}+3 \mathrm{TC}+\mathrm{NVP} \mathrm{n},(\%)$ & $10(22.2)$ \\
\hline & $\mathrm{AZT}+3 \mathrm{TC}+\mathrm{LPV} / \mathrm{r} \mathrm{n},(\%)$ & $1(2.2)$ \\
\hline \multicolumn{3}{|l|}{ CD4 count (cell/mm $\left.{ }^{3}\right)$} \\
\hline \multirow[t]{4}{*}{ at ART initiation } & Median (IQR) & $249(95-674)$ \\
\hline & $<200 \mathrm{n},(\%)$ & $19(42.22)$ \\
\hline & $200<\mathrm{CD} 4<500 \mathrm{n},(\%)$ & $24(53.3)$ \\
\hline & $>500 \mathrm{n},(\%)$ & $2(4.4)$ \\
\hline \multirow[t]{4}{*}{ at sample time } & Median (IQR) & $530(263-1220)$ \\
\hline & $<200 \mathrm{n},(\%)$ & 0 \\
\hline & $200<\mathrm{CD} 4<500 \mathrm{n},(\%)$ & $27(60)$ \\
\hline & $>500 \mathrm{n},(\%)$ & $18(40)$ \\
\hline \multicolumn{3}{|l|}{ Viral Load (VL) } \\
\hline \multirow[t]{4}{*}{$V L$ distribution at sample time } & Median (IQR) copies/ml & $184(86-400)$ \\
\hline & $\mathrm{VL}<50$ copies $/ \mathrm{ml} \mathrm{n}(\%)$ & $7(15.55)$ \\
\hline & $50<\mathrm{VL}<1000$ copies /ml n (\%) & $34(75.55)$ \\
\hline & $\mathrm{VL}>1000$ copies $/ \mathrm{ml} \mathrm{n}(\%)$ & $4(8.8)$ \\
\hline
\end{tabular}

$\mathrm{AZT}=$ Zidovudine, $3 \mathrm{TC}=$ Lamivudine, $\mathrm{NVP}=$ Nevirapine, $\mathrm{EFV}=$ Efavirenz, $\mathrm{TDF}=$ Tenofovir, $\mathrm{FTC}=$ Emticitadine, $\mathrm{LPV} / \mathrm{r}=$ Lopinavir boosted by ritonavir. ART: antiretroviral therapy.

\section{Discussion}

In this study we assessed the HIV-1 viral load and the rate of LTCD4+ in women living with HIV-1 in late 
pregnancy and we estimated the rate of HIV-1 transmission to their newborns in an associative health care center in N'djamena (Chad). According to WHO, a first line ART should allow virologic suppression after 24 weeks ( 6 months) of treatment (i.e. patient becomes undetectable VL $(<1.7 \log$ copies $/ \mathrm{ml}$ or $<50 \mathrm{copies} / \mathrm{ml}))$ and maintain this virologic suppression [22]. ART initiation for maternal health in this study leads to virologic suppression only in 7 women and for the remaining women, they were viremic with about $90 \%$ among them who had a VL $<3 \log$. Our observations in terms of viral load are similar to those of Rosalind J., et al. (2010), Sm Pignatelli et al. (2006) [23] [24]. The positive viral loads around 3log copies/ml in these pregnant women could be explained by the phenomena of Blips [25]. These blips, which are false positive results of the amount of virus present in the plasma [26]. All the women showed an immune restoration after median duration of treatment of 4 months. Our results are consistent with literature data [27]. This observation supports the interest of the use of ARVs drugs in pregnant women whose immune status is compromised due to their HIV infection [5] [6] [28] and secondly cause of their pregnancy [5]. In addition to the health of the pregnant woman, the goal of PMTCT is to prevent MTCT of HIV-1. In this study the rate of MTCT is estimated at (11.4\%) (4/35). Whatever the number of children tested is low, the rate of transmission, we found is high according to WHO recommendations that advocate for countries with limited resources, an MTCT rate $<2 \%$ [29]. Although transmission from mother-child HIV is multifactorial [6] [30], the effectiveness of ARVs for PMTCT has been proven as reported in numerous studies [14]-[16]. Thus, the number of children infected tested is worrying (4 of 35) and this highlights the postnatal HIV transmission cases. The contamination of these children might result from the practice of breastfeeding as reported by several studies [5] [6] [31]-[33]. This could also be a contamination in utero or per-native. Even our study has some limitations due to the study population size, which is low, the absence of VL level at ART initiation and lost of follow up in children, our findings showed that any woman in virologic suppression in late pregnancy has transmitted the virus to her child. It appears clearly that to obtain an undetectable VL in pregnant women on ART must be the challenge for effectiveness PMTCT program. A viral suppression is important, if not, especially in case of virus transmission to the child, they are most often minority variants selected by ART, which are transmitted to the infant [34]. The study showed a high proportion 10/45 $(22.2 \%)$ in terms of lost of follow up through the early infant diagnosis program, this could be explained by the deliberate refusal of mothers for the diagnosis of their child and/or change management site in order to avoid stigma and discrimination within the family. This was confirmed by previous studies [35]-[37]. Socio-demographic characteristics of the women included are similar to those reported in other studies in Africa [22]-[24].

\section{Conclusion}

Prevention of mother to child transmission of HIV-1 can be decentralized in associative health care centers for people living with HIV in N'djamena (Chad). It has been proven in previous studies that combination ART improves virological outcome of pregnant women [6] and restores their immune status. For an efficient and successful PMTCT program in associative field, an optimal adherence to treatment, the cornerstone of ART success must be promoted. It is important to inform mothers about the benefits of early infant diagnosis in HIV exposed children. It is also important to share with mothers about the risk of acquiring a postnatal transmission of HIV for their newborn and how to avoid it. Furthermore, the success of PMTCT needs availability of the viral load test in the country to monitor patients on ART.

\section{Acknowledgements}

We thank the Embassy of France in Chad and Togo through its SCAC service for their support. We express our deep gratitude to Dr. Alhassane BA international consultant, Dr. Goudjo ABDON advisor to the Ministry of Public Health of Chad, Mahamat Saleh Dr. coordinator APMS, and all laboratory technicians, pharmacists, counselors and staff of said center support.

\section{References}

[1] Alice, D. and Annabel, D.L. (2006) Les femmes africaines face à l'épidémie de sida. Population \& Sociétés n $428,4$.

[2] Kouyoumjian, S.P., Mumtaz, G.R., Hilmi, N., Zidouh, A., El Rhilani, H., et al. (2013) The Epidemiology of HIV Infection in Morocco: Systematicre View and Data Synthesis. International Journal of STD \& AIDS, 9, 507-516. http://dx.doi.org/10.1177/0956462413477971

[3] Peckham, C. and Gibb, D. (1995) Mother to Child Transmission of the Human Immunodeficiency Virus. The New 
England Journal of Medicine, 4, 298-302. http://dx.doi.org/10.1056/NEJM199508033330507

[4] Connor, E.M., Sperling, R.S., Gelber, R., Kiseley, P., Scott, G., O’Sullivan, M.J., et al. (1994) Reduction of Maternal Infant Transmission of Human Immunodeficiency Virus Type 1 with Zidovudine Treatment. Pediatric AIDS Clinical Trials Group Protocol 076 Study Group. The New England Journal of Medicine, 7, 1173-1180.

http://dx.doi.org/10.1056/NEJM199411033311801

[5] Renaud, B. and François, D. (2011) Prévention de la transmission mère-enfant du VIH en Afrique Wolters Kluwer France, 15.

[6] Soubeiga, S.T., Compaore, R., Djigma, F., Zagre, N., Assengone, E., Traore, L., et al. (2015) Evaluation du traitement antirétroviral chez les femmes enceintes VIH-1 positif, sur la transmission de l'infection de la mère à l'enfant: Cas du Centre Médical Saint Camille de Ouagadougou, au Burkina Faso. Pan African Medical Journal, 20, 399. http://www.panafrican-med-journal.com/content/article/20/399/pdf/399.pdf

[7] Dabis, F., Msellati, P., Meda, N., Welffens-Ekra., C., You, B., et al. (1999) 6-Month Efficacy, Tolerance, and Acceptability of a Short Regimen of Oral Zidovudine to Reduce Vertical Transmission of HIV in Breastfed Children in Cote d'Ivoire and Burkina Faso: A Double-Blind Placebo-Controlled Multicentre Trial. DITRAME Study Group. DIminution de la Transmission Mere-Enfant. Lancet, 6,786-792.

[8] Simpore, J., Pietra, V., Pignatelli, S., Karou, D., Nadembega, W.M., Ilboudo, D., et al. (2007) Effective Program against Mother-to-Child Transmission of HIV at Saint Camille Medical Centre in Burkina Faso. Journal of Medical Virology, 6, 873-879. http://dx.doi.org/10.1002/jmv.20913

[9] Pignatelli, S., Simpore, J., Pietra, V., Ouedraogo, L., Conombo, G., Saleri, N., et al. (2006) Factors Predicting Uptake of Voluntary Counselling and Testing in a Real-Life Setting in a Mother-and-Child Center in Ouagadougou, Burkina Faso. Tropical Medicine \& International Health, 7, 350-357. http://dx.doi.org/10.1111/j.1365-3156.2006.01564.x

[10] Sperling, R.S., Shapiro, D.E., Coombs, R.W., Todd, J.A., Herman, S.A., McSherry, G.D., et al. (1996) Maternal Viral load, Zidovudine Treatment, and the Risk of Transmission of Human Immunodeficiency Virus Type 1 from Mother to Infant. Pediatric AIDS Clinical Trials Group Protocol 076 Study Group. The New England Journal of Medicine, 8, 1621-1629. http://dx.doi.org/10.1056/nejm199611283352201

[11] Mandelbrot, L., Landreau-Mascaro, A., Rekacewicz, C., Berrebi, A., Benifla, J.L., Burgard, M., et al. (2001) Lamivudine-Zidovudine Combination for Prevention of Maternal-Infant Transmission of HIV-1. JAMA, 10, 2083-2093.

[12] Ioannidis, J.P., Abrams, E.J., Ammann, A., Bulterys, M., Goedert, J.J., Gray, L., et al. (2001) Perinatal Transmission of Human Immunodeficiency Virus Type 1 by Pregnant Women with RNA Virus Loads $<1000$ Copies/ml. The Journal of Infectious Diseases, 183, 539-545. http://dx.doi.org/10.1086/318530

[13] Dorenbaum, A., Cunningham, C.K., Gelber, R.D., Culnane, M., Mofenson, L., Britto, P., et al. (2002) Two-Dose Intrapartum/Newborn Nevirapine and Standard Antiretroviral Therapy to Reduce Perinatal HIV Transmission: A Randomized Trial. JAMA, 288, 189-198. http://dx.doi.org/10.1001/jama.288.2.189

[14] European Collaborative Study (2005) Mother-to-Child Transmission of HIV Infection in the Era of Highly Active Antiretroviral Therapy. Clinical Infectious Diseases, 7, 458-465.

[15] Achievements in Public Health (2006) Reduction in Perinatal Transmission of HIV Infection-United States, 19852005. Morbidity and Mortality Weekly Report, 5, 592-597.

[16] Tubiana, R., Matheron, S., Le Chenadec, J., Dollfus, C., Faye, A., Blanche, S., et al. (2011) Extremely Low Risk of Mother-to-Child Transmission of HIV in Women Starting HAART before Pregnancy in the French Perinatal Cohort (ANRS EPF CO1/11). CROI 2011.

[17] OMS (2006) Ampleur de la pandémie du VIH et SIDA. Prévention de la Transmission du VIH de la Mère à l'Enfant, Matériel Générique de Formation, Module 1, Module du Formateur. Organisation mondiale de la Santé, 4.

[18] OMS (2013) Consolidated Guidelines on the Use of Antiretroviral Drugs for Treating and Preventing HIV Infection: Recommendations for a Public Health Approach. http://www.who.int/iris/bitstream/10665/85321/1/9789241505727 eng.pdf

[19] CNLS (2013) Rapport sérosurveillance sentinelle du VIH chez les femmes enceintes pour l'année. Conseil National de Lutte Contre le Sida, 17, 7-28.

[20] Ministère de la sante publique (2012) Plan national d'élimination de la transmission du VIH de la mère à l'enfant au Tchad 2012-2015. Vol. 63, 12, 5-17.

[21] CNLS (2012) Rapport annuel sur le VIH au Tchad. Conseil National de Lutte Contre Le Sida, 9, 11-20.

[22] OMS (2005) La transmission du VIH par l'allaitement au sein: Bilan des connaissances actuelles. http://whqlibdoc.who.int/publications/2005/9242562718 fre.pdf

[23] Rosalind, J., Kate, D., Wafaa, M.E., Landon, M., Juliana, O., et al. (2010) CD4+ Cell Count Testing More Effective Than HIV Disease Clinical Staging in Identifying Pregnant and Postpartum Women Eligible for Antiretroviral Therapy 
in Resource-Limited Settings. JAID, 5, 404-410.

[24] Ruth, E.T., Heather, D.W., Li, D., Mark, V., Jane, P., Hunter, H., et al. (2005) Improved Obstetric Outcomes and Few Maternal Toxicities Are Associated With Antiretroviral Therapy Including Highly Active Antiretroviral Therapy During Pregnancy. JAID, 38, 449-473.

[25] Hocini, H. and Andreoletti, L. (2009) Méthodes d'analyse et de suivi de l'infection par les virus de l'immunodéficience humaine. Revue Francophone Des Laboratoires, 2009, 39-48. http://dx.doi.org/10.1016/S1773-035X(09)70308-9

[26] Eholié, S.P., Bennaï, Y., Courpotin, C., Ekouevi, D. and Raguin, G. (2009) Mémento thérapeutique du VIH/SIDA en Afrique 1, 70-71.

[27] Marie, L.N., Hoosen, C., Marjo, C.B., Nigel, R., Philippe, G. and Francois, D. (2004) Mortality of Infected and Uninfected Infants Born to HIV-Infected Mothers in Africa: A Pooled Analysis. Elsevier, 7, 1236-1243.

[28] Becquet, R., Bland, R.M., Ekouevi, D.K., Dabis, F. and Newell, M.L. (2010) Universal Antiretroviral Therapy among Pregnant and Postpartum HIV-Infected Women Would Improve Maternal Health and Decrease Postnatal HIV Transmission. AIDS, 24, 1239-1241. http://dx.doi.org/10.1097/QAD.0b013e328338b791

[29] Tang, J. and Nour, N.M. (2010) HIV and Pregnancy in Resource-Poor Settings. Reviews in Obstetrics and Gynecology, 5, 66-71.

[30] Kourtis, A.P., Bulterys, M., Nesheim, S.R. and Lee, F.K. (2001) Understanding the Timing of HIV Transmission from Mother to Infant. JAMA, 285, 709-712.

[31] Becquet, R. (2007) Antiretroviral Therapy among HIV-Infected Breastfeeding Mothers: A Promising Strategy to Prevent HIV Transmission through Breastmilk in Africa. Future HIV Therapy, 1, 17-21. http://dx.doi.org/10.2217/17469600.1.1.17

[32] Becquet, R., Bland, R., Leroy, V., Rollins, N.C., Ekouevi, D.K., Coutsoudis, A., et al. (2009) Duration, Pattern of Breastfeeding and Postnatal Transmission of HIV: Pooled Analysis of Individual Data from West and South African Cohorts. PLoS ONE, 4, e7397-e7401. http://dx.doi.org/10.1371/journal.pone.0007397

[33] Shapiro, R.L., Ndung'u, T., Lockman, S., Smeaton, L.M., Thior, I., et al. (2005) Highly Active Antiretroviral Therapy Started during Pregnancy or Postpartum Suppresses HIV-1 RNA, but Not DNA, in Breast Milk. The Journal of Infectious Diseases, 192, 713-719. http://dx.doi.org/10.1086/432489

[34] Monalisa, T.M., Junior, M., Ingrid, A.B., Lisa, M.F., Mqondisi, T., Justen, M., et al. (2015) The Burden of HIV Associated Drug Resistance Mutations in an Early Infant Diagnosis Program: A Glance through the Paediatric Window of Zimbabwe. Journal of Infectious Diseases and Therapeutics, 3, 198.

[35] Diack, M.A., Signate, S., Diagne Gueye, N.R., Ba, A., Sylla, A., Diouf, S., et al. (2005) Aspects epidemiologiques et cliniques de l'infection à VIH de l'enfant au centre hospitalier national d'enfants Albert-Royer à Dakar. Archives de Pédiatrie, 12, 404-409. http://dx.doi.org/10.1016/j.arcped.2005.01.011

[36] Mouffok, N., Errouane, K., Khellifi, M.L., Tahrour, M., Razik, F., et al. (2008) Le profil clinique et evolutif de l'infection à VIH chez l'enfant à l'ouest algerien. Médecine et Maladies Infectieuses, 38, S170-S172. http://dx.doi.org/10.1016/S0399-077X(08)73188-3

[37] d'Almeida, M., Sagbo, G., Lalya, F., Alao, M.J., d'Almeida, C., Agossou, J., et al. (2013) Profile of HIV-Infected Children at the University Hospital CNHU of Cotonou. CNHU, Cotonou, 6. 